\title{
Effect of Heavy Metal Content of some Common Spices Available in Local Markets in Erbil City on Human Consumption
}

\author{
Gulzar I. Ibrahim Lutfia M. Hassan Shirwan O. Baban Sirwan S. Fadhil
}

\author{
Department of Chemistry \\ College of Education /Scientific Departments \\ University of Salahaddin \\ Erbil - Iraq
}

(Received 22/11/2011;Accepted 14/2/2012)

\begin{abstract}
Herbs and spices are sources of many bioactive compounds that can improve the taste of foods as well as their influence on digestion and metabolism processes. They can also contain some undesirable components that can be harmful, e.g. micotoxins, pesticides, heavy metals, and polycyclic carbohydrates residues.

The objective of this study was to determine metals content in the most popular spices and herbs used in local market in Erbil. The content of these metals was assayed by Atomic absorption spectrophotometric method. The study showed differences in metal concentration according to the plant part (Rhizomes, Seed, Leaf, and fruit). The concentration ranged on dry basis were : ( 6.1-47.0), (56-650), (6-44), (10.5-22.5), (8.526.5), (26-88.6), (1.25-14.6), and (0.045-1.35) $\mathrm{mg} / \mathrm{kg}$ for the metals, $\mathrm{Zn}, \mathrm{Fe}, \mathrm{Cu}, \mathrm{Cr}, \mathrm{Co}$, $\mathrm{Mn}, \mathrm{Pb}$, and $\mathrm{Cd}$ respectively.

Most of the metal levels in the spices were acceptable with the exception of $\mathrm{Pb}, \mathrm{Cu}$ and $\mathrm{Cd}$ which were above the standard limit approved by World Health Organization (WHO) and Food Agriculture Organization (FAO), Pb was above the standard level for fenugreek, cinnamon, Cd was above the standard level for ginger.

Consumers of these spices would not be exposed to any risk associated with the daily in take of $10 \mathrm{~g}$ of spices per day containing the following metals; $\mathrm{Zn}, \mathrm{Fe}, \mathrm{Cu}, \mathrm{Cr}, \mathrm{Co}$, $\mathrm{Mn}$.but there are danger from fenugreek and cinnamon for $\mathrm{Pb}$, while the danger of ginger is from Cd.

Generally most of the spices available in the market are safe for human consumption except for $\mathrm{Pb}$ and $\mathrm{Cd}$.
\end{abstract}

Keywords: Heavy Metals, Spices, A.AS (Atomic Absorption Spectrophotometer). 


\section{تأثير العنالمر القيلة الموجوةفي بهض التولل المتوفرةفي الأسواق المحلية فيمدينة الربل عل الستهلي البشرى}

\section{الملغص}

الأعثلب والتوالبل مصادر للعديد من المركبلت الحيوية النشة التي يمكن أن تهشن طعم الطٔعمة

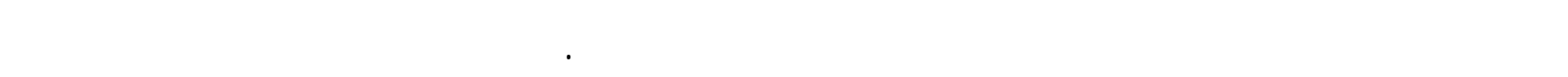

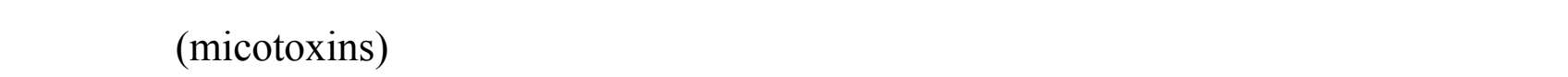
الهشرية والمعان القيلة وقايا الحلقات الكربوهيدراتية.

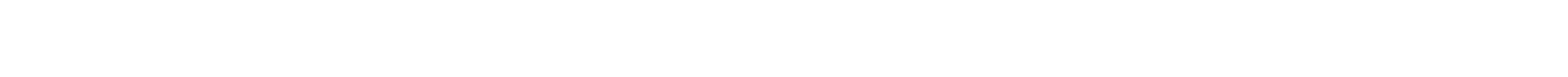

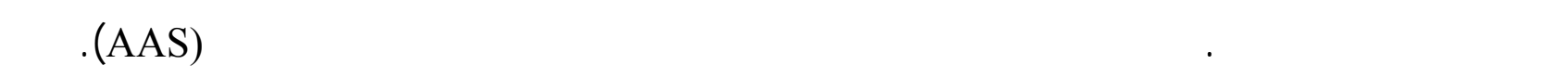
لظهرت الدرلسة الاختلاف في ترلكيز المعان وفقا لجزء النبت (الجذر وساق النبت والفولكه). إذ بلغت

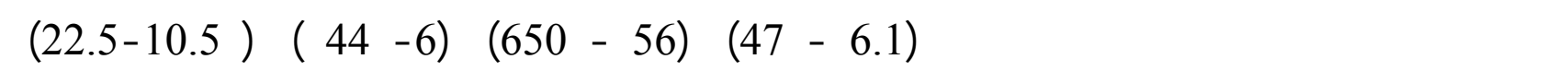

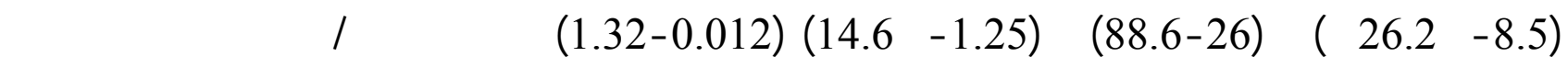
الخارصن و الحيد و النحلس و الكرو و الكوبلت و المنغنيز و الرصاص و الكاميوم على التوالي.

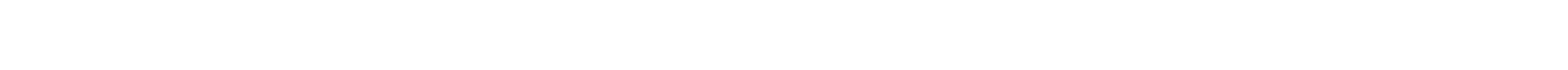

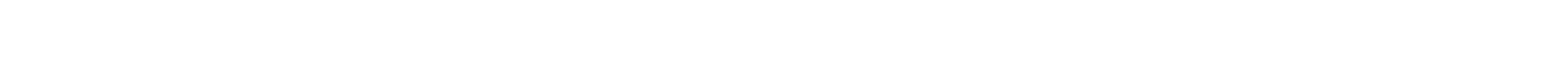

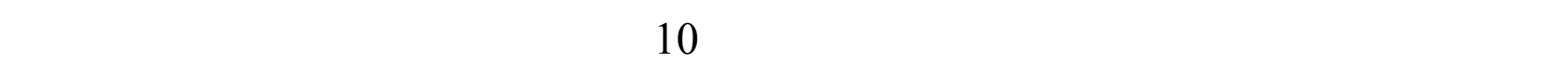

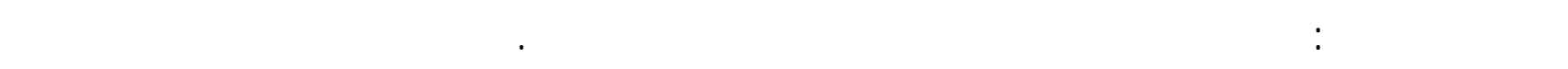

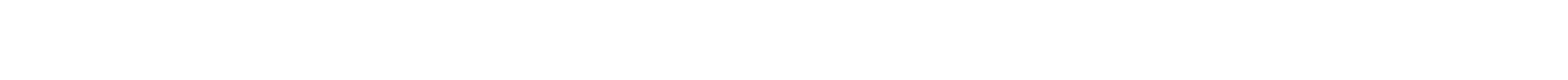
هي آمنة للمستهلاك البثري.

\section{INTRODUCTION}

In the last three decades, mainly because of their medicinal values, the use of spices and other herbs has increased markedly in most regions of the world, including Europe and North America. For instance, during this period, herbal medication in the USA has grown into an industry worth an average of 5billion per year, with projected annual growth of $15 \%$ ( Abebe, 2006).

Many common spices have outstanding antimicrobial effects. On the other hand, the process of preparation and handling can make them a source of food poisoning (Sherman and Billing, 1998).With the current emphasis on eating more healthy diets that are low in fat and salt, people are turning to various herbs and spices to flavor their food. The culinary herbs and spices that are used to enhance the flavor of vegetables, soups, stir-fry, and pasta dishes can be derived from the bark, buds, flowers, leaves, fruits, seeds, rhizome, or roots of a plant (Wahid et al., 1989). The presence of essential metals like iron, copper, manganese 
and zinc are very useful for the healthy growth of the body though very high levels are in tolerable, while metals like lead, cadmium etc are toxic at very low concentrations.

The addition of spices that may be contaminated the food as that may result in accumulation of these metals in human organs and lead to different health troubles (Al-Ed et al., 1997) these metals may reach and contaminate plants, vegetables, fruits and canned foods through air, water and soil during industrial processing and packaging (Ozores et al., 1997). The study of these heavy metals is crucial because they have potential hazardous effect, not only on compounds but human health as well. This is due to their cumulative behavior and toxicity although they are generally present in agricultural soils at low levels contamination (Ozkutlu et al., 2006). Monitoring the levels of heavy metal toxicity in spices would help ascertain the health impact of taking these spices, and provide relevant data on spices in the country.

Thus several studies were done to determine the concentration of heavy metals in spices, dry fruits and plant nuts (Gilbert, 1984; Husain et al., 1995) and to study their dang erous effect.

Kurdistan region imports spices among a lot of food stuffs from several countries. These spices may be subjected to contamination by so many ways as mentioned above, however, there is little information available about the safety of these spices with respect to heavy metals.

The main objective of this study was to determine the content of some heavy metals ( $\mathrm{Zn}, \mathrm{Fe}, \mathrm{Cu}, \mathrm{Cr}, \mathrm{Co}, \mathrm{Mn}, \mathrm{Pd}$, and $\mathrm{Cd}$ ) as available in local market of Erbil city in Kurdistan region.

\section{Sampling and Classification}

\section{MATERIAL AND METHODS}

Samples of common spices were collected from the local markets and divided according to the used part of the plant, their scientific, and local names are shown in (Table 1). Samples were kept in polythene bags and kept in a cool dry cardboard prior to analysis.

Table 1: Spice samples with their scientific and common name

\begin{tabular}{|c|c|c|c|}
\hline Common name & Scientific name & Family & Used part \\
\hline Black seed & Nigella Sativa & Anacardiaceae & Seed \\
\hline Cinnamon & Cinnamonum & Z(ylanicum Lauraceae & Rhizomes \\
\hline Mint & Menthe & Lamiaceae & Leaf $^{n}$ \\
\hline Fenugreek & Trigonella foenumgraecum & Legomnoseae & Seed \\
\hline Black peper & Capsicum nigrum & Piperaceae & Seed \\
\hline Ginger & Zingiber afficenalis & Zingiberaceae & Rhizomes \\
\hline Turmeric & Cuccuma longa & Zingiberaceae & Rhizomes \\
\hline Omani lime & citrus aurantifolia & Rutaceae & Fruit \\
\hline Coriander & Coriandium sativum & Umbellifeae or Apiaceae & Seed \\
\hline Sumac fruit & Rhus Coriaria & Folium & Fruit \\
\hline Cumin & Cuminum cyminum & Umbellifeae or Apiaceae & Seed \\
\hline Cardamon & Elettaria cardamonum & Zingiberaceae & Seed \\
\hline
\end{tabular}




\section{Experimental Procedures}

Samples were cleaned and oven-dried at $80{ }^{\circ} \mathrm{C}$ for $\approx 12 \mathrm{hrs}$ before chemical analysis. The dried samples were ground in a mortar with pestle till, a fine powder was obtained. The powder was sieved with a $0.5 \mathrm{~mm}$ mesh and kept dry for analysis.

Instrumental: metal measurement was performed with (Pye unicam SP9) Atomic Absorption Spectrophotometer, double beam and deuterium background correction. Measurement were done against metal standard solution. For flaming air-acetylene was used..

Standards: The standard stock solutions for the following metals were prepared as follows:

$\mathrm{Zn}: 1000 \mathrm{ppm}$ of $\mathrm{Zn}$ was prepared by dissolving $0.8040 \mathrm{gm}$ of zinc oxide in $5 \mathrm{ml}$ of deionized water followed by $25 \mathrm{ml}$ of $5 \mathrm{M}$ hydrochloric acid. Diluted to 1 liter in volumetric flask with deionized' water.

Fe: $1000 \mathrm{ppm}$ of Fe was prepared by dissolving $1.000 \mathrm{gm}$ of iron powder in $20 \mathrm{ml}$ of $5 \mathrm{M}$ hydrochloric acid and $5 \mathrm{ml}$ of nitric acid. Diluted to 1 liter in volumetric flask with deionized water.

$\mathrm{Cu}: 1000 \mathrm{ppm}$ of $\mathrm{Cu}$ was prepared by dissolving $1.000 \mathrm{gm}$ of $\mathrm{Cu}$ metal in $50 \mathrm{ml}$ of $5 \mathrm{M}$ nitric acid. Diluted to 1 liter in volumetric flask with deionized water.

Cr: $1000 \mathrm{ppm}$ of $\mathrm{Cr}$ was prepared by dissolving $7.690 \mathrm{gm}$ of chromium nitrate in $250 \mathrm{ml}$ of deionized water. Diluted to 1 liter in volumetric flask with deionized water.

Co: $1000 \mathrm{ppm}$ of Co was prepared by dissolving $4.0380 \mathrm{gm}$ of cobalt(11) chloride in $200 \mathrm{ml}$ of deionized water. Diluted to 1 liter in volumetric flask with deionized water.

Mn: $1000 \mathrm{ppm}$ of Mn was prepared by dissolving $3.6077 \mathrm{gm}$ of manganese dichloride in $50 \mathrm{ml}$ hydrochloric acid. diluted to 1 liter in volumetric flask with deionized water.

$\mathrm{Pb}: 1000 \mathrm{ppm}$ of $\mathrm{Pb}$ was prepared by dissolving $1.5980 \mathrm{gm}$ of lead nitrate in $100 \mathrm{ml}$ of deionized water. Diluted to 1 liter in volumetric flask with deionized water.

$\mathrm{Cd}$ : $1000 \mathrm{ppm}$ of $\mathrm{Cd}$ was prepared by dissolving $1.1423 \mathrm{gm}$ of cadmium oxide in $20 \mathrm{ml}$ of $5 \mathrm{M}$ hydrochloric acid. Diluted to 1 liter in volumetric flask with deionized water.

For determination of heavy metal concentrations, a wet digestion of the dried samples was done according to the method described by Jones and Case (1990) using mixture of concentrated $\mathrm{H}_{2} \mathrm{SO}_{4}$ and $30 \% \mathrm{H}_{2} \mathrm{O}_{2}$. To a $0.5 \mathrm{~g}$ of dry- ground sample was added $3.5 \mathrm{ml}$ of $30 \% \mathrm{H}_{2} \mathrm{O}_{2}$ and $2 \mathrm{ml}$ of $\mathrm{H}_{2} \mathrm{SO}_{4}$. The mixture was heated to $100{ }^{\circ} \mathrm{C}$, and the temperature was gradually increased to $250{ }^{\circ} \mathrm{C}$, and left at this temperature for $30 \mathrm{~min}$ then cooled and an additional $1 \mathrm{ml}$ of $30 \% \mathrm{H}_{2} \mathrm{O}_{2}(\mathrm{v} / \mathrm{v})$ was added, the mixture were reheated. The digestion process was repeated more than one time until a clear solution was obtained (Kalra, 1998). The clear solution was transferred into a $25 \mathrm{ml}$ volumetric flask, and completed to the mark with double distilled water. A blank digestion solution was made for comparison, containing $3.5 \mathrm{ml}$ of $30 \% \mathrm{H}_{2} \mathrm{O}_{2}(\mathrm{v} / \mathrm{v})$ and $2 \mathrm{ml}$ of concentrated $\mathrm{H}_{2} \mathrm{SO}_{4}$, the solution transferred into 25 $\mathrm{ml}$ volumetric flask and completed to the mark with double distilled water. Calibration standards were prepared by dilution of the high purity commercial metal standard for atomic absorption analysis, metal measurement was performed with ( Pye unicam SP9) Atomic Absorption Spectrophotometer, double beam and deuterium background correction. Measurement were done against metal standard solution. 


\section{RESULTS AND DISCUSSION}

Essential metal ( $\mathrm{Zn}, \mathrm{Fe}, \mathrm{Cu}, \mathrm{Cr}, \mathrm{Co}, \mathrm{Mn})$ and Heavy metal $(\mathrm{Pb}$ and $\mathrm{Cd})$ analyses have been performed on 12 local spices and the outcome has been presented in (Table 2). The Values of metal concentration were compared with maximum permissible standard concentration of $50,300,20,30,50,100,10,0.2 \mathrm{mg} / \mathrm{kg}$ respectively as recommended by WHO 2005.

The WHO limit of Zinc is not to be exceeded $50 \mathrm{mg} / \mathrm{kg}$. However, the range of zinc was $6.1 \mathrm{mg} / \mathrm{kg}$ for fenugreek to $47.0 \mathrm{mg} / \mathrm{kg}$ for black seed ( Fig. 1). It was very well below the limit and may be considered tolerable. A study in Nigeria on food however was showed relatively low levels of zinc $0.06-56.9 \mathrm{mg} / \mathrm{kg}$ (Oninwa et al., 2001).

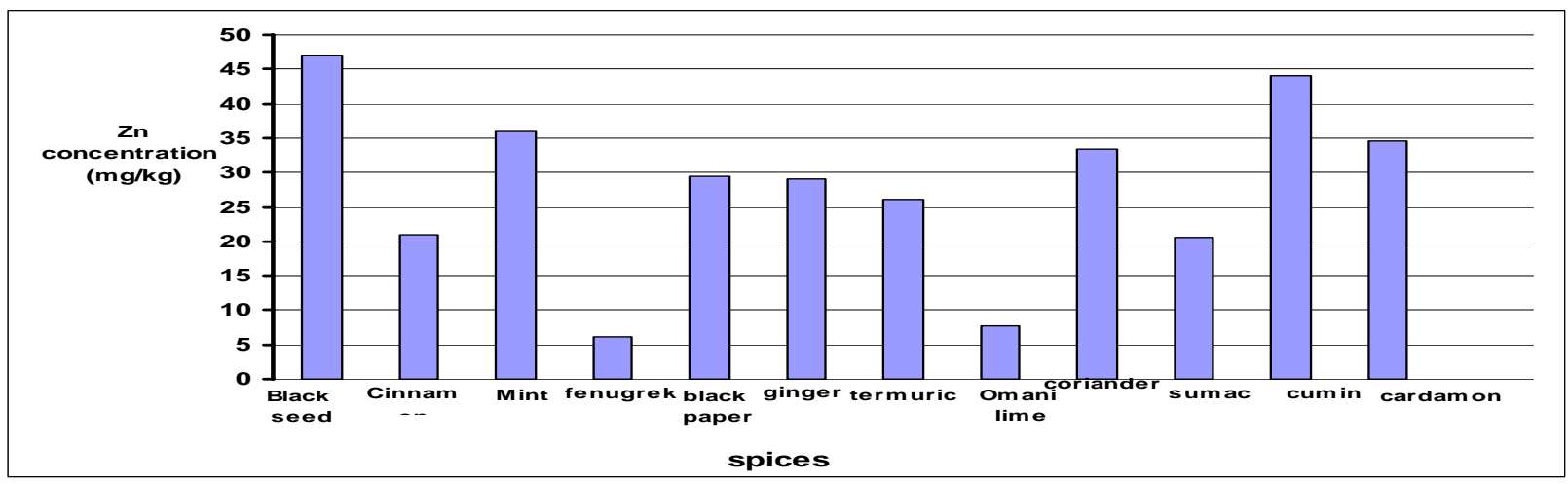

Fig. 1 : Levels of $\mathrm{Zn}$ in different spices

Iron has a relatively high WHO level in foods. As revealed by analytical results (Table 2) iron content of spices samples ranged between $56.0 \mathrm{mg} / \mathrm{kg}$ for cardamom and 650 $\mathrm{mg} / \mathrm{kg}$ for mint (Fig. 2). Although there was a high content of iron in all the samples. Iron intake from spices has no effect on health.

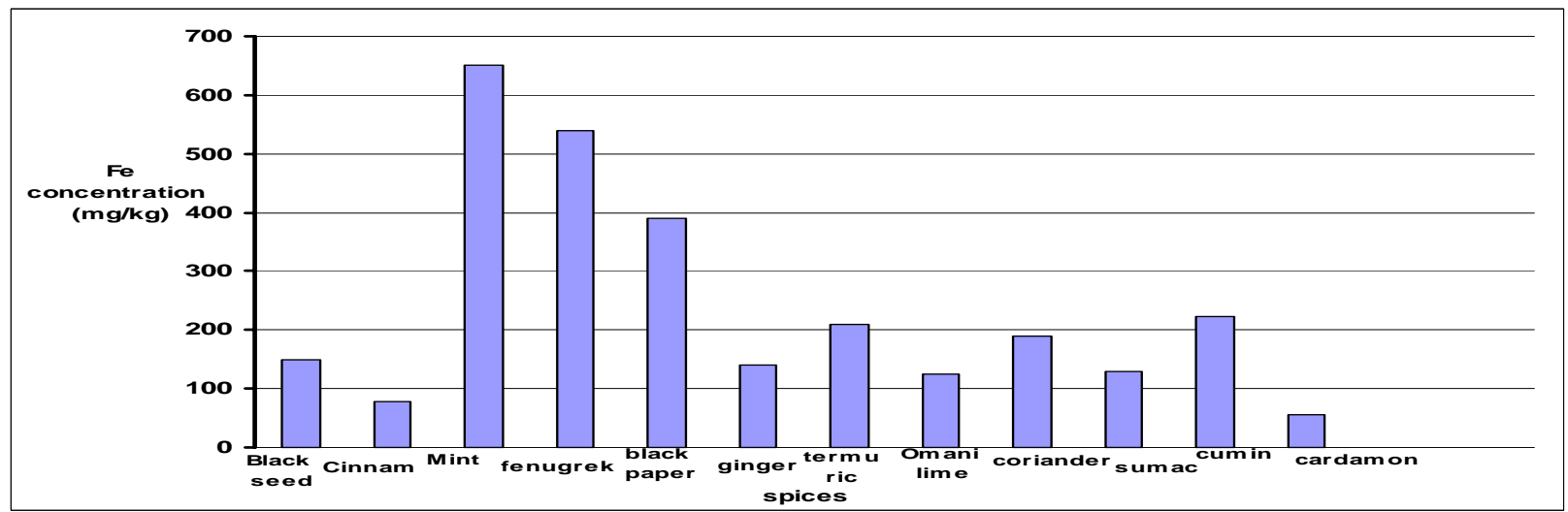

Fig. 2 : Levels of Iron in different spices 
Table 2: Elements concentration (mg/kg) on dry weight basis of studied common spices.

\begin{tabular}{|c|c|c|c|c|c|c|c|c|}
\hline $\begin{array}{c}\text { Name of } \\
\text { spices }\end{array}$ & Zn & Fe & Cu & $\mathrm{Cr}$ & Co & Mn & $\mathbf{P b}$ & Cd \\
\hline $\begin{array}{l}\text { Black } \\
\text { seed }\end{array}$ & $47.0 \pm 2.1$ & $150 \pm 1.0$ & $13.7 \pm 0.24$ & $10.5 \pm 1.0$ & $15.3 \pm 1.2$ & $45.0 \pm 1.2$ & $2.1 \pm 0.1$ & $\begin{array}{c}0.156 \pm 7.6 * 10- \\
3\end{array}$ \\
\hline Cinnamon & $21 \pm 0.10$ & $78.0 \pm 0.7$ & $6.0 \pm 2.2$ & $12.5 \pm 0.1$ & $11.1 \pm 0.5$ & $58.0 \pm 1.74$ & $11.7 \pm 0.12$ & $0.18 \pm 0.02$ \\
\hline Mint & $36.0 \pm 0.86$ & $650 \pm 1.9$ & $16.0 \pm 1.6$ & $22.5 \pm 0.1$ & $14 \pm 0.4$ & $45.0 \pm 0.3$ & $6.6 \pm 1.2$ & $0.05 \pm 0.1$ \\
\hline Fenugreek & $6.1 \pm 0.1$ & $540 \pm 2.6$ & $11.6 \pm 1.51$ & $18.5 \pm 0.2$ & $8.5 \pm 0.1$ & $73.0 \pm 1.34$ & $14.6 \pm 1.31$ & $0.033 \pm 0.034$ \\
\hline $\begin{array}{l}\text { Black } \\
\text { paper }\end{array}$ & $29.4 \pm 1.77$ & $390 \pm 1.6$ & $19.2 \pm 2.2$ & $\begin{array}{c}11.5 \pm \\
0.53\end{array}$ & $9.5 \pm 0.2$ & $52 \pm 2.2$ & $3.8 \pm 1.99$ & $0.046 \pm 0.02$ \\
\hline Ginger & $29.0 \pm 0.4$ & $140 \pm 1.9$ & $15.2 \pm 1.44$ & $16.0 \pm 0.1$ & $8.6 \pm 0.45$ & $88.6 \pm 1.99$ & $7.2 \pm 1.11$ & $1.32 \pm 0.022$ \\
\hline Termuric & $26.0 \pm 0.29$ & $210 . \pm 2.3$ & $23.8 \pm 2.1$ & $16.0 \pm 0.3$ & $15.0 \pm 0.42$ & $\begin{array}{c}26.8 \pm \\
1.43\end{array}$ & $3.9 \pm 0.1$ & $0.012 \pm 0.01$ \\
\hline $\begin{array}{l}\text { Omani } \\
\text { lime }\end{array}$ & $7.7 \pm 2.1$ & $125 \pm 1.8$ & $44.0 \pm 0.26$ & $13.5 \pm 0.17$ & $19.0 \pm 0.56$ & $51.5 \pm 1.33$ & $3.7 \pm 0.14$ & $0.019 \pm 0.1$ \\
\hline Coriander & $33.4 \pm 2.2$ & $190 \pm 0.93$ & $\begin{array}{l}18.0 \pm \\
0.078\end{array}$ & $\begin{array}{c}18.45 \pm \\
0.11\end{array}$ & $\begin{array}{c}26.2 \pm \\
.066\end{array}$ & $29.9 \pm 2.1$ & $4.1 \pm 0.13$ & $0.061 \pm 0.045$ \\
\hline Sumac & $20.5 \pm 0.51$ & $130 \pm 0.67$ & $44.0 \pm 0.12$ & $\begin{array}{l}10.5 \pm \\
0.15\end{array}$ & $5.0 \pm 0.21$ & $\begin{array}{c}26.0 \pm \\
1.43\end{array}$ & $5.5 \pm 0.17$ & $0.045 \pm 0.02$ \\
\hline Cumin & $\begin{array}{c}44.0 \pm \\
0.53\end{array}$ & $\begin{array}{c}222.3 \pm \\
1.6\end{array}$ & $9.3 \pm 0.56$ & $13.9 \pm 0.12$ & $10 \pm 0.43$ & $26.9 \pm 1.57$ & $2.2 \pm 0.15$ & $0.13 \pm 0.055$ \\
\hline Cardamon & $\begin{array}{c}34.5 \pm 0 . \\
32\end{array}$ & $\begin{array}{c}56.0 \pm \\
0.42\end{array}$ & $14.45 \pm 0.32$ & $\begin{array}{c}12.5 \pm \\
0.16\end{array}$ & $15 \pm 1.1$ & $\begin{array}{c}81.4 \pm \\
0.71\end{array}$ & $1.25 \pm 0.1$ & $0.14 \pm 0.24$ \\
\hline
\end{tabular}

Copper content of spices samples ranged between $6.0 \mathrm{mg} / \mathrm{kg}$ for cinnamon to $44 \mathrm{mg} / \mathrm{kg}$, for sumac and Omani lime (Fig. 3). The Daily intake was much less than maximum permission limit. Copper intake from spices has no effect on health if it is taken in trace amount but can be toxic in high level.

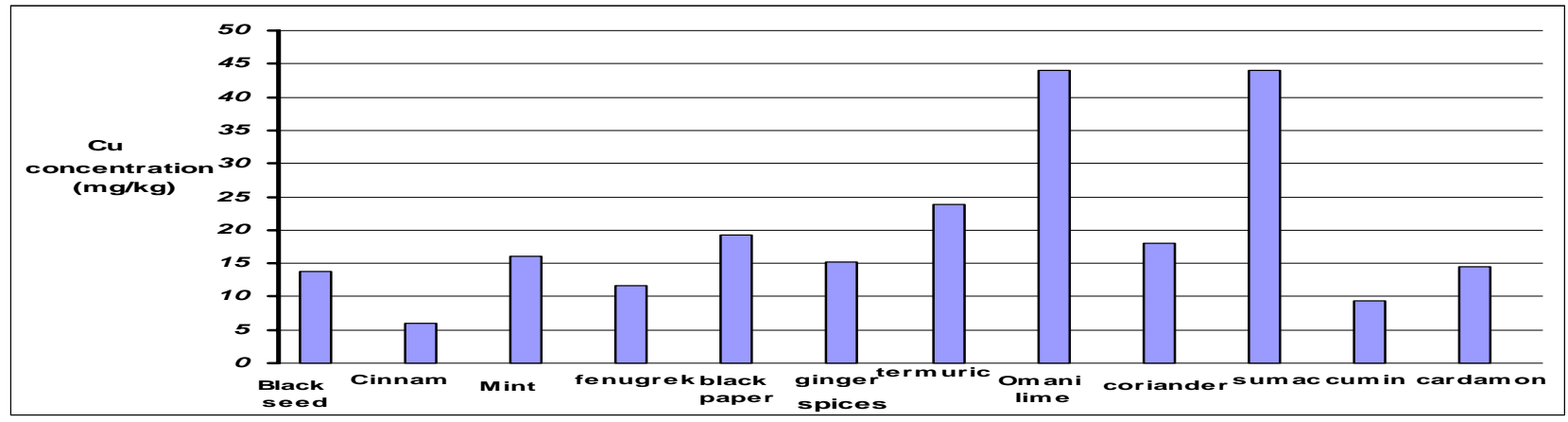

Fig. 3: Levels of cupper in different spices

In case of chromium highest mean concentration was found for mint leaf $22.5 \mathrm{mg} / \mathrm{kg}$ and lowest was for black seed, sumac $10.5 \mathrm{mg} / \mathrm{kg}$ (Fig. 4). Chromium particularly Cr (III) plays an important role in the body function in trace amount but it is toxic in excess amount. Daily intake values were less than the maximum permission limit values and it is not a bright line for health risk. 


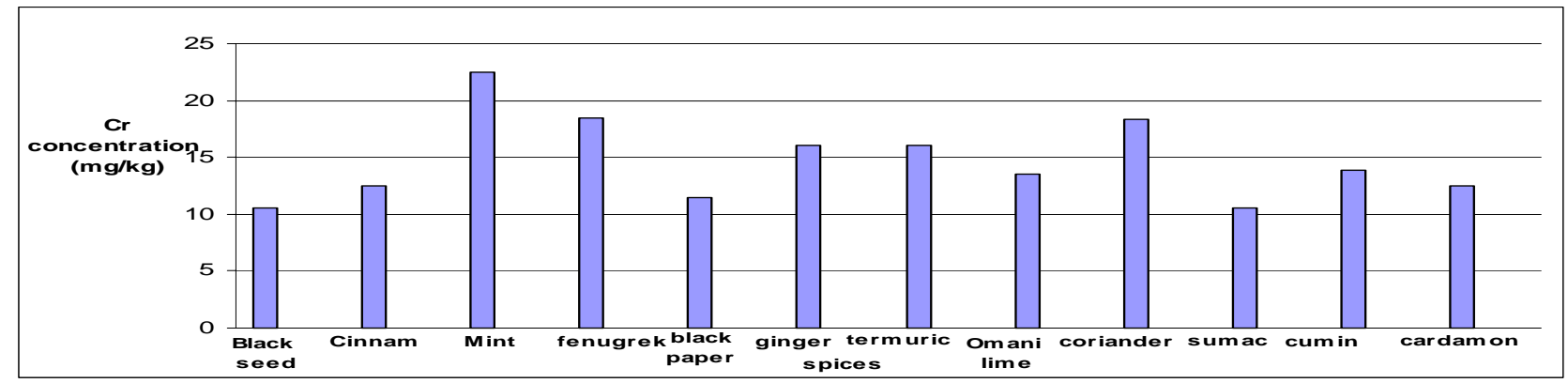

Fig. 4 : Levels of chromium present in different spices

In case of cobalt there was varied level in concentration for all samples ranging from $8.5 \mathrm{mg} / \mathrm{kg}$ for fenugreek to $26.2 \mathrm{mg} / \mathrm{kg}$ for coriander (Fig. 5). Daily intake values were found to be much lower than maximum permission level values so there is no effect on health due to cobalt intake, from spices. Although cobalt is toxic at elevated levels, however the body needs small amount of cobalt in the form of vitamin B12 which is in active physiological form (Weir et al., 1999).

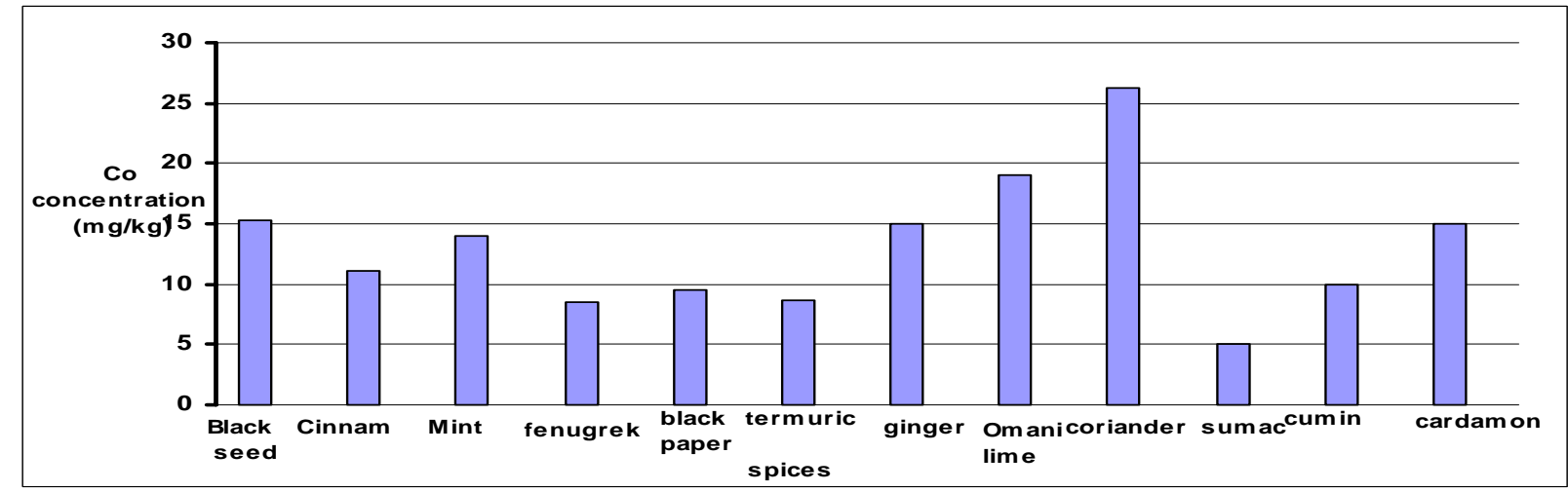

Fig. 5 : Levels of cobalt in different spices

In case of Manganese there was small variation in concentration for all the samples ranging from $26.0 \mathrm{mg} / \mathrm{kg}$ for sumac and $88.6 \mathrm{mg} / \mathrm{kg}$ for ginger (Fig. 6). Daily intake were found lower than maximum permission level value.

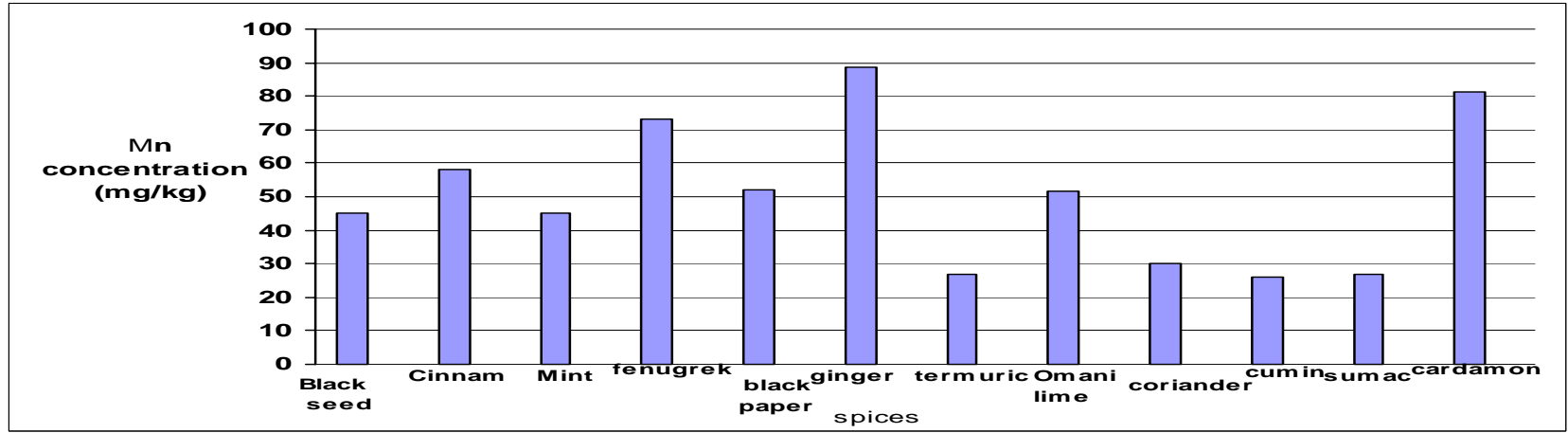

Fig. 6 : Levels of Manganese in different spices

Lead content in cinnamon and fenugreek have levels of 11.7 and $14.6 \mathrm{mg} / \mathrm{kg}$ respectively, which are marginally above the WHO limit of $10 \mathrm{mg} / \mathrm{kg}$ (Fig. 7). The 
relatively high levels of lead might have resulted from accumulation of lead through air pollution, inclusion or absorption at the mill during grinding, and from some pesticides, such as lead arsenates, applied during cultivation. It means intake of spices under this study can cause lead accumulation in body. It has been reported to competitively inhibit lead uptake in cells (Loum et al., 1991). Lead is a heavy metal poison which forms complexes with oxo-groups in enzymes to affect virtually all steps in the processes of heamoglobin synthesis and porphyrin metabolism (Ademorati, 1996). Toxic levels of lead in man have been associated with encephalopathy seizures and mental retardation (Schumann, 1990).

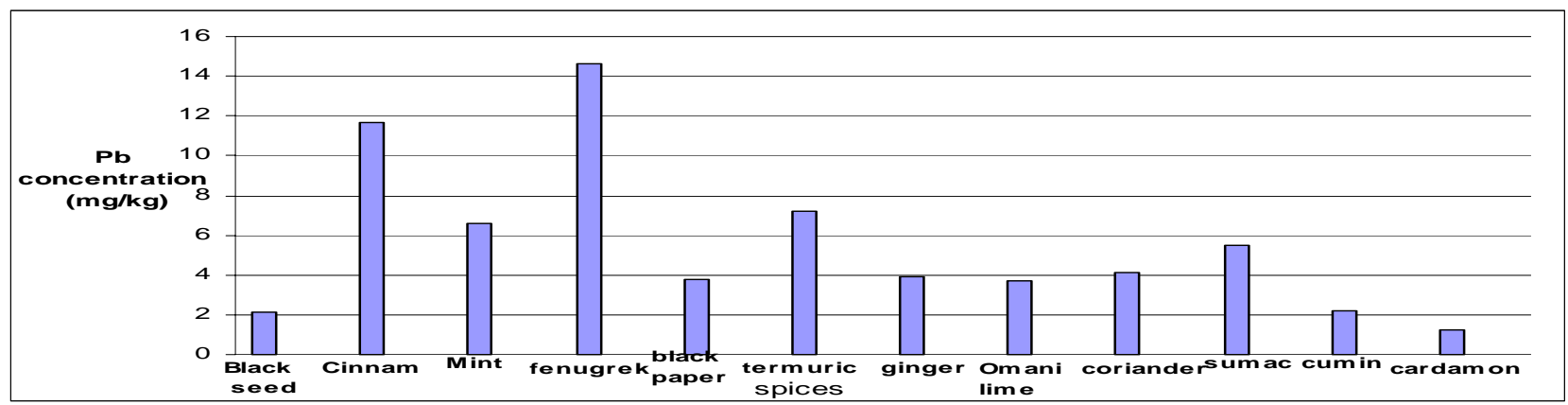

Fig.7 : Levels of lead in different spices

There was a little variation in case of cadmium. The concentration ranged between $0.012 \mathrm{mg} / \mathrm{kg}$ for turmeric to $1.3 \mathrm{mg} / \mathrm{kg}$, for ginger (Fig. 8). The maximum permissible limit concentration $\left(0.2 \mathrm{mg} \cdot \mathrm{kg}^{-1}\right)$ of cadmium is referred by (FAO/WHO 1984). The high level of cadmium might be due to the use of cadmium-containing fertilizers or from the practice of growing this plant with sewage sludge or both, these result may agree with what reported by (Chizzola et al., 2003).

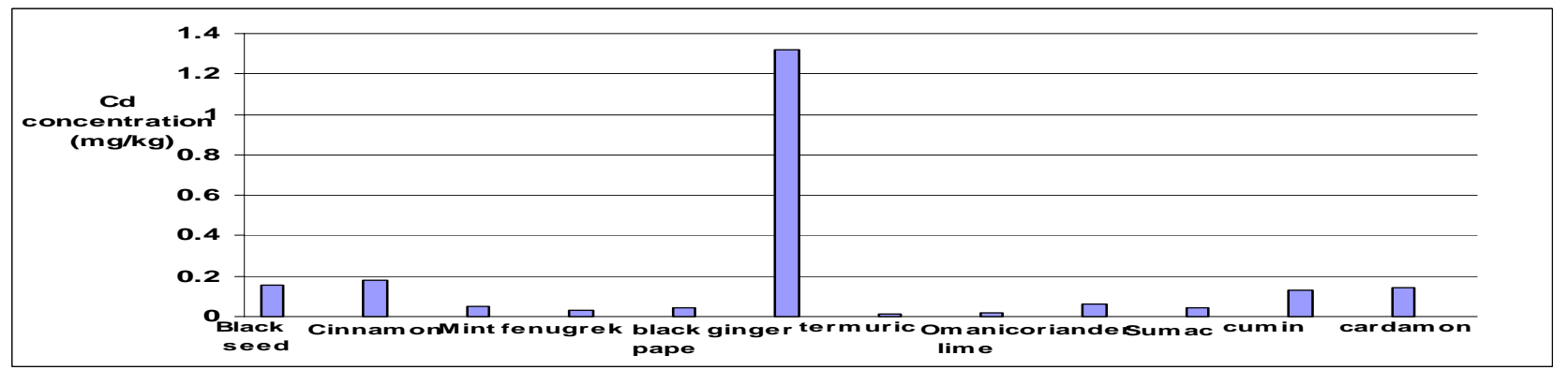

Fig. 8 : Levels of cadmium in different spice

\section{CONCLUSION}

The content of toxic metals in plant spices was generally found to be low, the analyzed sample was shown to be elevated in lead and cadmium respectively.

The highest content of lead and cadmium was shown in fenugreek, ginger and cinnamon. The contents of zinc ,chromium, cobalt, and manganese in spices was relatively low and met the appropriate safety standard and was high at some range for iron and copper which has no effect on the health

On the basis of results it can be concluded that the majority of the spices used in the Erbil are not contaminated with heavy metals except a few cases of cinnamon, ginger and fenugreek .Excessive use of these could therefore pose a health hazard to consumers. 


\section{REFERENCES}

Abebe, W. (2006). Potential health benefits of spices used in ethiopian cuisines. Ethiop Med. J., 44 (2), 133-8.

Ademorati, C.M.A. (1996). "Environmental Chemistry and Toxicology Pollution by Heavy Metals". Foludex Press Ltd., Ibadan. pp.171-172

Al-Eed, M. A.; Assubaie, F.N.; El-Garawany, M.; EL- Hamshary, H. ; El-Tayeb, Z.M. (1997). "Determination of Heavy Metal levels in Common Spices". Department of Botany, College of Agricultural \& Food Sciences, King Faisal University, P.O. Box 420, Al-Hasa 31982, Saudi Arabia

Chizzola, R.; Michitch, H.; Franz, C.H. (2003). Monitoring of metallic micronutrients and heavy metals in herbs, spices and medicinal plants from Austria. Eur. Food Res. Technol., 216-407

FAO/WHO. (1984). Joint FAO/WHO Food Standard Program, Codex Alimentarius Commission Contamination, CAC, vol.XV11. FAO. Roma and WHO, Genava

Gilbert, J. (1984). "Analysis of Food Contamination". 1st edn., Elsevier App. Sci. London, ISBN: 0-85334-255-5

Husain, A.; Baroon, Z.; Al-Khalafawi, S. ; Al-Ati, T. ; Sawaya, W. ( 1995). Heavy metals in fruits and vegetables grown in Kuwait during the oil well fires. Arab Gulf J. Sci. Research., 13(3), 535-542.

Jones, J.B. ; Case, V. W. (1990). Sampling, Handling and analyzing Plant Tissue Samples. In: Westerman, R.L. (ed.), Soil Testing and Plant Analysis, 404-409. Madison

Kalra, Y. P. (1998). Handbook of reference methods for plant analysis. CRC Press, Science, 57.

Lou, M. ; Garray, R. ; Alda, J. (1991). Cadmium uptake through the anion exchanger in human red blood cells. J. Physiol., 443, 123-126

Oninwa, P.C.; Adeyemo, A. O.; Idowu, A. O. ; Ogabiela, E. E. (2001). Copper and Zinc contents of Nigerian foods and estimates of the adult dietary intakes, Food Chemistry, 72, 89-95.

Ozkutlu, F.; Sekeroglu, N.; Kara, S. M. (2006).Monitoring of cadmium and micro nutrients in spices commeny cousumed in turkey. Res.J. Agric. and Biol. Sci., 2(5), 223-226.

Ozores, H. M.; Hanlon, E.; Bryan, H.; Schaffer, B. (1997). Cadmium, copper, lead, nickel and zinc concentrations in tomato and squash grown in MSW compost amended calcareous soil. Compost Sci. and Utilization. 5 (4), 40-45.

Schumann, K. (1990). The toxicological estimation of the heavy metal content (Cd, Hg, Pb) in food for infants and small children. Z. Ernahrungswiss, 29(1), 54-73.

Sherman, W. P.; Billing, J. (1998). Antimicrobial functions of spices: why some like it hot. Quarterly Review of Biol., 73(3), 1-47

Wahid, M.; Satter, A.; Durrani, S. K. (1998). Concentration of selected heavy metals in spices, dry fruits and plant nuts. Plant Food and Human Nutrition, 39(3), 279-286

Weir, D. G.; Scott, J. M. (1999). Cobalamines physiological, Dietary sources and requirements. Encyclopedia of Human Nutrition, 1, 394-401

World Health Organization. (2005). "Quality Control Methods for Medicinal Plant Materials", Genava. 